\title{
Effect of Training on Various Anthropometric and Physiological Profiles of Tribal Children in Tripura 訓練對印度部落兒童體型及生理的影響
}

\author{
Swapan Kumar DEY \\ Human Performance Laboratory, \\ Sports Authority of India, INDIA
}

庫馬爾戴伊

印度體育局人體行為實驗室

\author{
Sangita PAL \\ Sports Medicine Centre \\ Netaji Indoor Stadium \\ Kolkata, INDIA
}

沙積堤帕爾

印度加爾各答運動醫學中心

\begin{abstract}
A proper and systematic use of physical training can enhance physiological improvement. The present study was aimed to investigate the effects of formal training programs on different physical and physiological profiles of prepubescent tribal boys at different age group. The study was conducted on 69 young boys who were divided into three subgroups i.e. GroupI $(n=23$, age=9.3 \pm 0.19$)$, Group-II $(n=18$, age=10.1 \pm 0.86$)$, Group-III $(n=28$, age $=11 \pm 0.22)$ according to their chronological age. All the boys were inducted in Tripura sports school having formal training of 18 months. Another 64 boys were also chosen as control group (sedentary in nature) from the same community. They were also divided into three subgroups as per their respective test groups. All the boys including sedentary groups belong to similar socio-economic status and dietary habits. Tests were conducted three times in 18 months duration on test groups and twice in control groups to evaluate the height, weight, hand grip strength, body fat\%, endurance ability, speed ability, explosive power of the lower extremities and hemoglobin\% of all the boys. The result of the present study revealed that almost all the parameters were increased significantly in all three test groups after 18 months duration, except body fat\% which was found to be changes insignificantly in group II boys. When the comparison was made among the groups, it was observed that in pre training, all the parameters were changed significantly at $\mathrm{p}<0.01 \&$ body fat $\%$ at $\mathrm{p}<0.05$ level except $800 \mathrm{~m}$ run and standing broad jump (SBJ) respectively. Significant differences were also observed following 18 months of training in height, hemoglobin percent, $800 \mathrm{~m}$ run at the level of $\mathrm{p}<0.05$ and weight, hand grip strength, 30m flying start, aerobic capacity, $\mathrm{SBJ}$ at $\mathrm{p}<0.01$ levels, except body fat\% which was found to be statistically insignificant. All the parameters were found to be more in Test group-III as compared to other two groups. Prior to training no such significant differences were observed in above parameters with respect to control group. Following 18 months of training, a significant difference was found with respect to control group in all parameters except height, weight (Gr-I \& Gr- II) \& body fat\%. However the increase in above anthropometric and physiological parameters may only because of the augmenting effect of training or due merely because of their growth \& development. It has been reported that moderate physical training is necessary for normal growth \& development and it is more pronounced in the subject who belongs at the trigger point of adolescence. So it may be concluded that under same nutritional status the effect of formal training is more effective in higher age group as compared to the lower age group.
\end{abstract}

Key Words: Adolescent, Growth \& development, Physiological profiles, Training 


\section{摘 要}

本文旨在探討印度部落兒童, 透過運動訓練而影響的體型及生理變化。邀請了69名兒童進行評估及比較, 結果顯示: 大 部份體型及生理指標有明顯的增長。

\section{Introduction}

The physique and physical condition are the important components which determine the athlete's performance. Carter (1970) and Tanner (1964) studied \& reported that body size and physique are important selective factors in particular sports because size and shape of the body influence several physiological variables that are important for sports performance. The athletic characteristics of the individual can be expressed through motor qualities such as speed, strength, power, flexibility, balance, agility, and endurance in which some are more dominant then others and have directly relation with motor fitness (Barrow \& Rosemary 1979).

It is well known that children's are naturally active (Blair, 1992; Bar-O, 1989) and almost involved short burst of intense exercise through daily tasks, games or sports event (Van Praagh, 2000) and the variability of physiological responses to maximal exercise observed during growth and maturation. Gillian and Freedson (1980) stated that a maturational factor may determine a child's potential for physiological alteration to occur consequent to physical training. The term growth is usually expressed in absolute term such as change in height and weight. On the other hand development is often used in broad sense to include both growth and maturation as they relate to the function of the system of the body (Malina \& Bouchard, 1991). The growth and developmental pattern of any population is influenced by genetical, constitutional, environmental, socioeconomic, and nutritional status and endocrine factors as reported by Raghavan (1971). However, a wide range of differences from population to population and lot of diversity in term of geographical, ethnical and racial factors etc are exist in different region of India.

Malina (1994) and Shephard (1984) have reported that linear growth is slightly affected by a moderate training. A growing child passes through various stages of growth and development and motor development is one of the most important aspects of growth and development. The development of various motor abilities has different velocities at different age. Training enhances physiological improvement, specific exercise and overload must be followed (Veadmir \& Zatsiorsky, 1995). The effects of training on aerobic performance in pre-pubertal boys have produced equivocal result but the review of literature have recently concluded that young boys will show an improvement in their peak VO2 with appropriate training programme, which may be less than the older youth and adults (Armstrong 1990; Pate 1990). Some studies has also reported that training induced improvement in peak $\mathrm{VO}_{2} \max$ (Weltman, 1987; Savage, 1986) on the other hand no significant changes have observed in peak $\mathrm{VO}_{2} \max$ (Becker 1983; Gillian and Freedson 1980). It has also been reported, a well designed training programme can enhance the fitness of an average prepubescent child by 10\%-15\% (Rowland, 1995; Shephard, 1992). Initially young children have lack of motor skill to benefit from many types of physical activity. If training programme is continued for months and even years a good response does emerge (Shephard, 1993). Generally training areas focus on the improvement of athletics' skill and development of a specific energy which is predominant to a particular sports event. High levels of habitual, physical activity have been proposed (Krahenbuhl, 1985) as a reason for blunted training responses in children.

The present study is focused on anthropometric and physiological characteristics of young players in relation to growth, maturation and training. The physical demands of the game are multi factorial and it is very necessary to adapt to this demand to become a successful player. It is unpredictable to find out whether the "training" plays a vital role in growing children to develop different physical \& physiological parameters or other factors like nutrition, genetical \& geographical variation etc. have some influence on them. Therefore, the present study was undertaken (i) To evaluate the various anthropometric and physiological profiles of the boys of Tripura Tribes, (ii)to analyze and compare the differences if any of selected anthropometric and physiological profiles between pre and post training, (iii) to study and compare the growth and development pattern of the boys according to their chronological age, (iv)to study the relationship among the various anthropometric 
and physiological parameters at different stages of growth and development.

\section{Methods}

Sixty-nine young boys comprises three different group that is Gr-I $(n=23)$, Gr-II $(n=18)$, Gr-III $(n=28)$ were chosen for the present study. They were selected for the induction in Tripura Sports School (residential) at Agartala, Tripura. Sixty four boys were also chosen as control for three different groups that is for $\mathrm{Gr}$ I $(n=21)$, Gr-II $(n=18)$, Gr-III $(n=25)$ respectively. These boys (control groups) were considered according to the ages of test group and who were sedentary in nature. The subjects of the present study belong to the tribal community of Tripura specially Reang, Darlong, Jamatia, Debbarma, etc. who were mongoloid in origin. The subjects were selected on the basis of a set of physical fitness test and the subject those who fail to qualify the screening test were not considered for admission. On the other hand only those boys who had been participating in physical education program of the school curriculum were considered as control group for the present study. The sports school boys were receiving systematic sports training by qualified coaches/trainer, since there induction in school (2 to 3 years). The training protocol was consists of general conditioning, endurance and strength training for 2-3 hours, five days per week. During this period skill training including games/match play was also included. All the anthropometric and physiological data were collected three times in test groups i.e at the time of induction (test-I), after 12 months (test-II) \& 18 months (test-III) from the time of induction respectively. In case of control groups tests were conducted twice i.e before and after 18 months of training periods.

Before the test, all the players were clinically examined by doctor, specialized in sports medicine. Prior to initial testing a complete explanation of the purposes, procedure, potential risk and benefits of the test were explained to all players and a written consent was obtained from all the players and their parents/legal guardians. The players who were found clinically fit, healthy and no history of any heart and lung diseases was finely selected for the study. In the present study decimal age (calculated from their date of birth as recorded at the time of testing), height, weight, fat $\%$, hand grip strength, and various motor ability test were measured. The purpose of the test was explained to each of the players and the method of testing was demonstrated to all. All question put foreword by the subjects were answered.

Height. The body height was measured by a portable stadiometer (SECA, Vogel and Halke, Germany) to the nearest millimeter.

Weight. The body weight was measured, using SECA electronic scales, to the nearest $0.1 \mathrm{~kg}$. Both were measured with the child in light clothing (school tracksuit) without shoes. All the parameters were measured by following standard procedure.

Grip Strength. Each participant performed hand grip isometric strength test using a dynamometer (Senoh, Japan) according to standard procedures. Each participant performed three trials \& the best score was recorded for each participant in both right \& left hand separately.

Body Fat. The body fatness was measured from Skin fold thicknesses using Digital Skin-fold caliper (Skindex, USA) at the site of biceps, triceps, sub scapular and suprailliac (Eston et al. 1995). Body density was calculated using the equation of Siri (1961) and body fat $\%$ was calculated by the formula of Durnin and Womersley (1974).

VO 2 max. The $20 \mathrm{~m}$ multistage physical fitness test (Leger \& Lambert 1982) was used to measure cardiorespiratory status or maximum oxygen uptake capacity. This test has been found to be a valid predictor of $\mathrm{VO}_{2}$ max in children \& adolescents (Boreham et al. 1990; van Mechelen et al. 1986).

Motor ability. The motor ability parameters were measured by means of standard test (Dey et al. 1997) to asses the different motor qualities like speed (30m flying start), power of lower limb (SBJ) \& short term endurance (800m run).

Haemoglobin percentage. The blood samples of the subjects were analyzed for hemoglobin percent by cyanmathaemoglobin method of Dacie and Lewis (1975). 


\section{Statistical Analysis}

Statistical Package for Social Sciences (SPSS) version 17.0 was used for the analysis. Data was subjected to statistical treatment like descriptive statistics. Repeated Measures analysis of variance (ANOVA), followed by Bonferroni Post Hoc Test, was applied to assess the difference among three tests of each group and also applied one way analysis of variance (ANOVA), followed by Tukey HSD Post Hoc Test to assess the difference between three groups in each test. Statistical significance was accepted, at a level of $p<0.05$. 2-tailed $t$-test was performed to see whether any significant differences exist between the test groups \& control group.

\section{Results}

Table 1 represented the mean (SD) values of different physical and physiological parameters of the boys of Gr-I, Gr-II, and Gr-III of three subsequent test conducted at the time of induction (Test-I), after 12months (Test-II) and 18 months (Test-III) respectively. It was observed from the table that a linear increased in height \& weight in all the groups (Gr-I, Gr-II \& Gr-III) during the period and the maximum rate of improvements were observed in test-II when compared to test-I. Grip strength (right \& left) and SBJ also showed similar rate of improvements as it was observed in height \& weight. In test-III, the right \& left hand grip strength were found to be more in Gr-I than the Gr-II. in test-I and test-III. The table further revealed that $30 \mathrm{~m}$ run time was gradually decreased throughout the period in all the groups which was measured in three subsequent test phases. No such gradual increase/decrease was seen incase of body fat $\%$ in all the groups when compared among them during the 18 months periods of formal training. Almost similar result was observed like fat $\%$ in case of hemoglobin level. The endurance capacity of the boys (bleep test and $800 \mathrm{~m}$ run) were linearly improved in all the groups the time i.e., timing of the $800 \mathrm{~m}$ run was found to be deteriorated at end of the training session.

Table 2 represented the change in various physical and physiological parameters of Group-I, Group-II and Group-III boys in the course of three subsequent tests conducted at the time of induction, after 12 months and 18 months respectively. In Gr-III, all the parameters were found to be increased significantly at $\mathrm{P}<0.01$ level after 18 months of induction, except body fat $\%$ which was found to be significant at the level of $\mathrm{P}<0.05$ after 18 months of training. However, body fat $\%$ was found to be statistically insignificant when compared between test-I vs test-II and test-I vs test-III. On the other hand $\mathrm{Hb} \%$ was found to be insignificant when compared between test-I vs test-II. But test-I vs test-III and test-II vs test-III were found to be significant when compared between them. Like Gr-III, changes of all the physical and physiological parameters of Gr-II boys were also found to be significant at $\mathrm{p}<0.01$ level except body fat $\%$ which was found to be totally insignificant. Changes in $\mathrm{Hb} \%$ found to be similar as observed in Gr-III boys when compared among the test phases. Significant differences were observed in GrI boys among the three test phases at $\mathrm{p}<0.01$ level in all the parameters. No such significant difference was observed in $30 \mathrm{~m}$ flying start in test II vs test III. The table further revealed that an insignificant difference was observed in $800 \mathrm{~m}$ run between test I vs test II.

Table 3 represented the comparison of different physical and physiological parameters among the groups during the period of 18 months i.e. test-I, test-II, and test-III respectively. Test-I result showed that a significant difference $(\mathrm{p}<0.01)$ in height, weight, hand grip strength(both right and left), $\mathrm{Hb} \%, 30 \mathrm{~m}$ flying start, aerobic capacity $\left(\mathrm{VO}_{2}\right.$ $\max )$ and body fat $\%(\mathrm{p}<0.05)$ when compared among the groups. However, no such significant differences were observed in case of $800 \mathrm{~m}$ run \& explosive power of lower limbs (SBJ) when compared among the groups. All most all the parameters were found to be statistically insignificant when compared between Gr-I vs Gr-II except $30 \mathrm{~m}$ run, body fat $\&$ hemoglobin percent which were found to be statistically significant. All the parameters were changes significantly and no such significant differences were observed in body fat \& $\mathrm{Hb} \%, 800 \mathrm{~m}$ run and SBJ when compared between Gr-II vs Gr-III. On the other hand almost similar observations were made in Gr-II vs Gr-III as per Gr-I vs Gr-III. In test-II, all the physical and physiological profiles were found to be statistically significant when compared among the groups except body fat\%, which was found to be statistically insignificant. However, most of the parameters were insignificant between Gr-II vs Gr-III and Gr-I vs Gr-II respectively. All most similar observations were also made in test-III as it was observed in test-II. 
Table 4 represented the various changes in physical and physiological profiles of the boys of Gr-I, Gr-II and Gr-III with their respective control groups at the time of induction and after 18 months of induction respectively. It was noted from the table that none of the parameters were found to be significantly different when compared Gr-I, Gr-II and Gr-III with their respective control groups (at the time of induction). The values were found to be slightly higher in the boys of test groups as compared to the boys of control groups in most of the cases. On the other hand when test groups were compared with their respective control groups after 18 months of training almost all the values except height, weight (Gr-I \& I) \& fat $\%$ were found to be significantly higher in the test groups (Gr-I, Gr-II \& Gr-III).

Table 1. Mean $( \pm$ SD) of Different Physical \& Physiological Profiles of three Different Age Groups in three Subsequent Test Phases.

\begin{tabular}{|c|c|c|c|c|c|c|c|c|c|}
\hline \multirow[b]{2}{*}{ PARAMETERS } & \multicolumn{3}{|c|}{ GROUP-I } & \multicolumn{3}{|c|}{ GROUP-II } & \multicolumn{3}{|c|}{ GROUP-III } \\
\hline & TEST-I & TEST-II & TEST-III & TEST-I & TEST-II & TEST-III & TEST-I & TEST-II & TEST-III \\
\hline HEIGHT(cm) & $\begin{array}{l}141.89 \\
( \pm 6.78)\end{array}$ & $\begin{array}{c}148.02 \\
( \pm 8.06)\end{array}$ & $\begin{array}{r}149.24 \\
( \pm 8.46)\end{array}$ & $\begin{array}{l}147.03 \\
( \pm 3.76)\end{array}$ & $\begin{array}{l}152.28 \\
( \pm 3.37)\end{array}$ & $\begin{array}{l}153.72 \\
( \pm 3.21)\end{array}$ & $\begin{array}{r}149.09 \\
( \pm 9.50)\end{array}$ & $\begin{array}{l}154.64 \\
( \pm 9.03)\end{array}$ & $\begin{array}{l}155.46 \\
( \pm 8.86)\end{array}$ \\
\hline WEIGHT(kg) & $\begin{array}{l}32.24 \\
( \pm 4.18)\end{array}$ & $\begin{array}{c}37.13 \\
( \pm 5.43)\end{array}$ & $\begin{array}{r}38.35 \\
( \pm 5.50)\end{array}$ & $\begin{array}{l}35.06 \\
( \pm 2.47)\end{array}$ & $\begin{array}{r}40.39 \\
( \pm 2.57)\end{array}$ & $\begin{array}{r}41.89 \\
( \pm 2.47)\end{array}$ & $\begin{array}{l}39.05 \\
( \pm 7.05)\end{array}$ & $\begin{array}{c}43.54 \\
( \pm 7.51)\end{array}$ & $\begin{array}{c}45.70 \\
( \pm 7.16)\end{array}$ \\
\hline GRIP (Rt) (kg) & $\begin{array}{l}15.17 \\
( \pm 4.59)\end{array}$ & $\begin{array}{c}18.52 \\
( \pm 5.11)\end{array}$ & $\begin{array}{r}23.57 \\
( \pm 3.78)\end{array}$ & $\begin{array}{l}14.78 \\
( \pm 4.08)\end{array}$ & $\begin{array}{c}19.61 \\
( \pm 3.82)\end{array}$ & $\begin{array}{r}22.78 \\
( \pm 4.82)\end{array}$ & $\begin{array}{l}23.96 \\
( \pm 5.97)\end{array}$ & $\begin{array}{c}26.04 \\
( \pm 5.80)\end{array}$ & $\begin{array}{c}29.96 \\
( \pm 5.34)\end{array}$ \\
\hline GRIP (Lt) $(\mathrm{kg})$ & $\begin{array}{l}13.61 \\
( \pm 4.38)\end{array}$ & $\begin{array}{l}17.00 \\
( \pm 5.51)\end{array}$ & $\begin{array}{r}22.22 \\
( \pm 3.75)\end{array}$ & $\begin{array}{c}14.22 \\
( \pm 3.86)\end{array}$ & $\begin{array}{c}17.44 \\
( \pm 3.79)\end{array}$ & $\begin{array}{c}20.94 \\
( \pm 4.84)\end{array}$ & $\begin{array}{c}20.93 \\
( \pm 5.52)\end{array}$ & $\begin{array}{c}23.82 \\
( \pm 5.32)\end{array}$ & $\begin{array}{c}27.93 \\
( \pm 4.79)\end{array}$ \\
\hline Fat $\%$ & $\begin{array}{l}9.56 \\
( \pm 2.27)\end{array}$ & $\begin{array}{l}8.67 \\
( \pm 2.44)\end{array}$ & $\begin{array}{r}8.13 \\
( \pm 2.49)\end{array}$ & $\begin{array}{l}8.02 \\
( \pm 1.63)\end{array}$ & $\begin{array}{r}8.32 \\
( \pm 1.62)\end{array}$ & $\begin{array}{c}8.32 \\
( \pm 1.76)\end{array}$ & $\begin{array}{c}8.53 \\
( \pm 1.56)\end{array}$ & $\begin{array}{c}9.06 \\
( \pm 1.68)\end{array}$ & $\begin{array}{r}8.55 \\
( \pm 1.69)\end{array}$ \\
\hline $\mathrm{Hb} \%$ & $\begin{array}{l}11.17 \\
( \pm 0.71)\end{array}$ & $\begin{array}{l}10.56 \\
( \pm 0.65)\end{array}$ & $\begin{array}{r}12.29 \\
( \pm 0.80)\end{array}$ & $\begin{array}{l}12.16 \\
( \pm 0.81)\end{array}$ & $\begin{array}{c}11.54 \\
( \pm 0.73)\end{array}$ & $\begin{array}{c}12.65 \\
( \pm 0.67)\end{array}$ & $\begin{array}{c}11.19 \\
( \pm 0.78)\end{array}$ & $\begin{array}{c}11.24 \\
( \pm 0.81)\end{array}$ & $\begin{array}{c}12.96 \\
( \pm 0.90)\end{array}$ \\
\hline $\begin{array}{l}\text { 30M RUN } \\
(\mathrm{sec})\end{array}$ & $\begin{array}{l}4.65 \\
( \pm 0.26)\end{array}$ & $\begin{array}{c}4.21 \\
( \pm 0.38)\end{array}$ & $\begin{array}{r}4.17 \\
( \pm 0.32)\end{array}$ & $\begin{array}{c}4.43 \\
( \pm 0.22)\end{array}$ & $\begin{array}{c}4.14 \\
( \pm 0.24)\end{array}$ & $\begin{array}{c}3.94 \\
( \pm 0.15)\end{array}$ & $\begin{array}{c}4.39 \\
( \pm 0.21)\end{array}$ & $\begin{array}{c}3.95 \\
( \pm 0.31)\end{array}$ & $\begin{array}{c}3.83 \\
( \pm 0.27)\end{array}$ \\
\hline $\begin{array}{l}\text { 800M RUN } \\
(\mathrm{sec})\end{array}$ & $\begin{array}{l}175.38 \\
( \pm 14.88)\end{array}$ & $\begin{array}{c}172.94 \\
( \pm 12.66)\end{array}$ & $\begin{array}{r}163.10 \\
( \pm 14.64)\end{array}$ & $\begin{array}{l}174.54 \\
( \pm 10.17)\end{array}$ & $\begin{array}{c}162.22 \\
( \pm 8.77)\end{array}$ & $\begin{array}{c}154.35 \\
( \pm 6.32)\end{array}$ & $\begin{array}{r}175.66 \\
( \pm 10.80)\end{array}$ & $\begin{array}{c}165.40 \\
( \pm 17.65)\end{array}$ & $\begin{array}{l}157.54 \\
( \pm 10.83)\end{array}$ \\
\hline $\mathrm{SBJ}(\mathrm{mt})$ & $\begin{array}{l}1.96 \\
( \pm 0.18)\end{array}$ & $\begin{array}{c}2.02 \\
( \pm 0.20)\end{array}$ & $\begin{array}{r}2.12 \\
( \pm 0.20)\end{array}$ & $\begin{array}{c}2.00 \\
( \pm 0.13)\end{array}$ & $\begin{array}{c}2.16 \\
( \pm 0.12)\end{array}$ & $\begin{array}{c}2.26 \\
( \pm 0.11)\end{array}$ & $\begin{array}{c}1.94 \\
( \pm 0.14)\end{array}$ & $\begin{array}{r}2.23 \\
( \pm 0.16)\end{array}$ & $\begin{array}{c}2.27 \\
( \pm 0.17)\end{array}$ \\
\hline $\begin{array}{l}\mathrm{VO}_{2} \mathrm{MAX} \\
(\mathrm{ml} / \mathrm{kg} / \mathrm{min})\end{array}$ & $\begin{array}{l}47.67 \\
( \pm 4.54)\end{array}$ & $\begin{array}{l}50.62 \\
( \pm 4.78)\end{array}$ & $\begin{array}{r}53.97 \\
( \pm 5.32)\end{array}$ & $\begin{array}{c}47.93 \\
( \pm 4.13)\end{array}$ & $\begin{array}{r}52.28 \\
( \pm 3.34)\end{array}$ & $\begin{array}{c}55.83 \\
( \pm 4.52)\end{array}$ & $\begin{array}{c}52.08 \\
( \pm 5.01)\end{array}$ & $\begin{array}{c}56.79 \\
( \pm 4.37)\end{array}$ & $\begin{array}{c}60.96 \\
( \pm 4.72)\end{array}$ \\
\hline
\end{tabular}




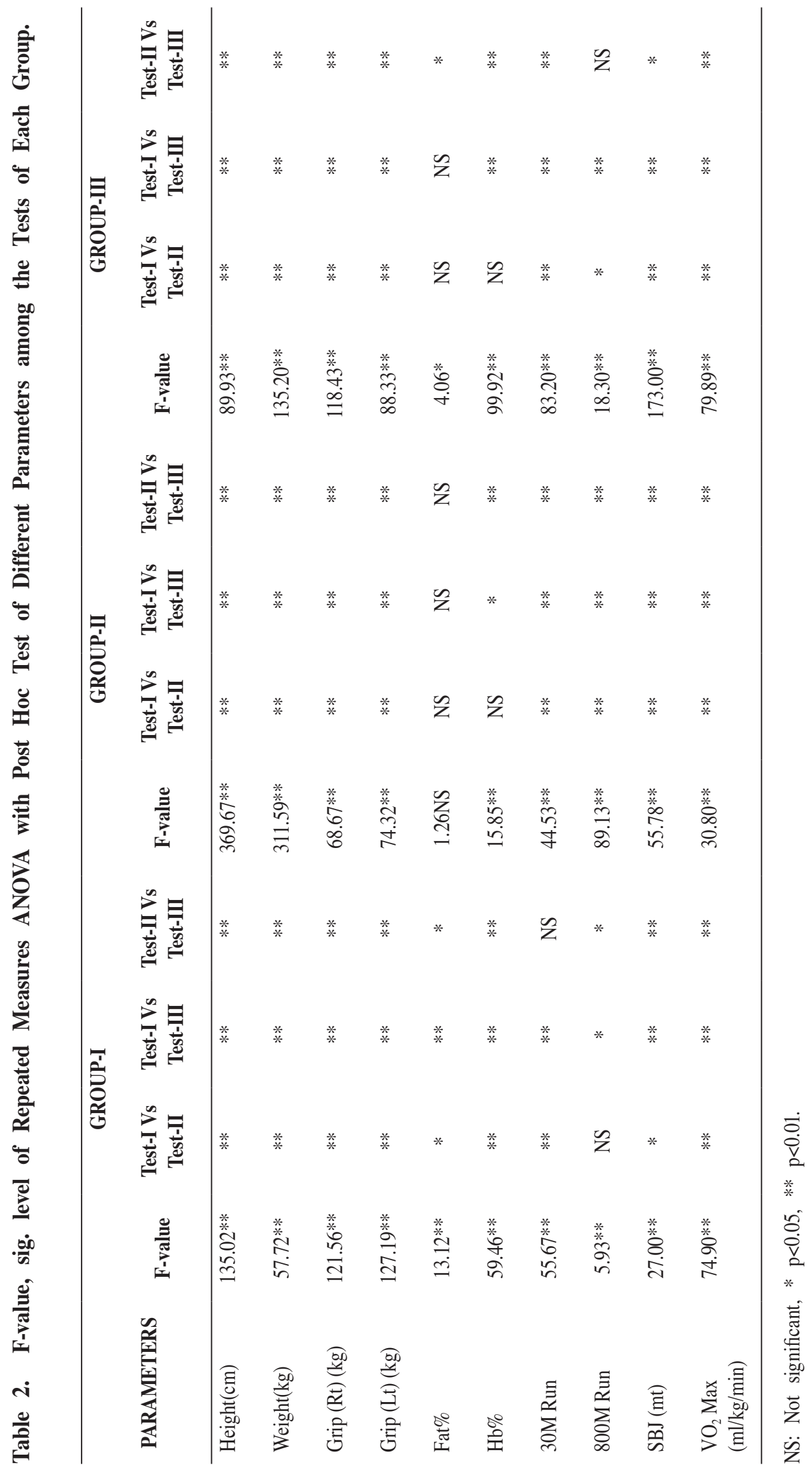




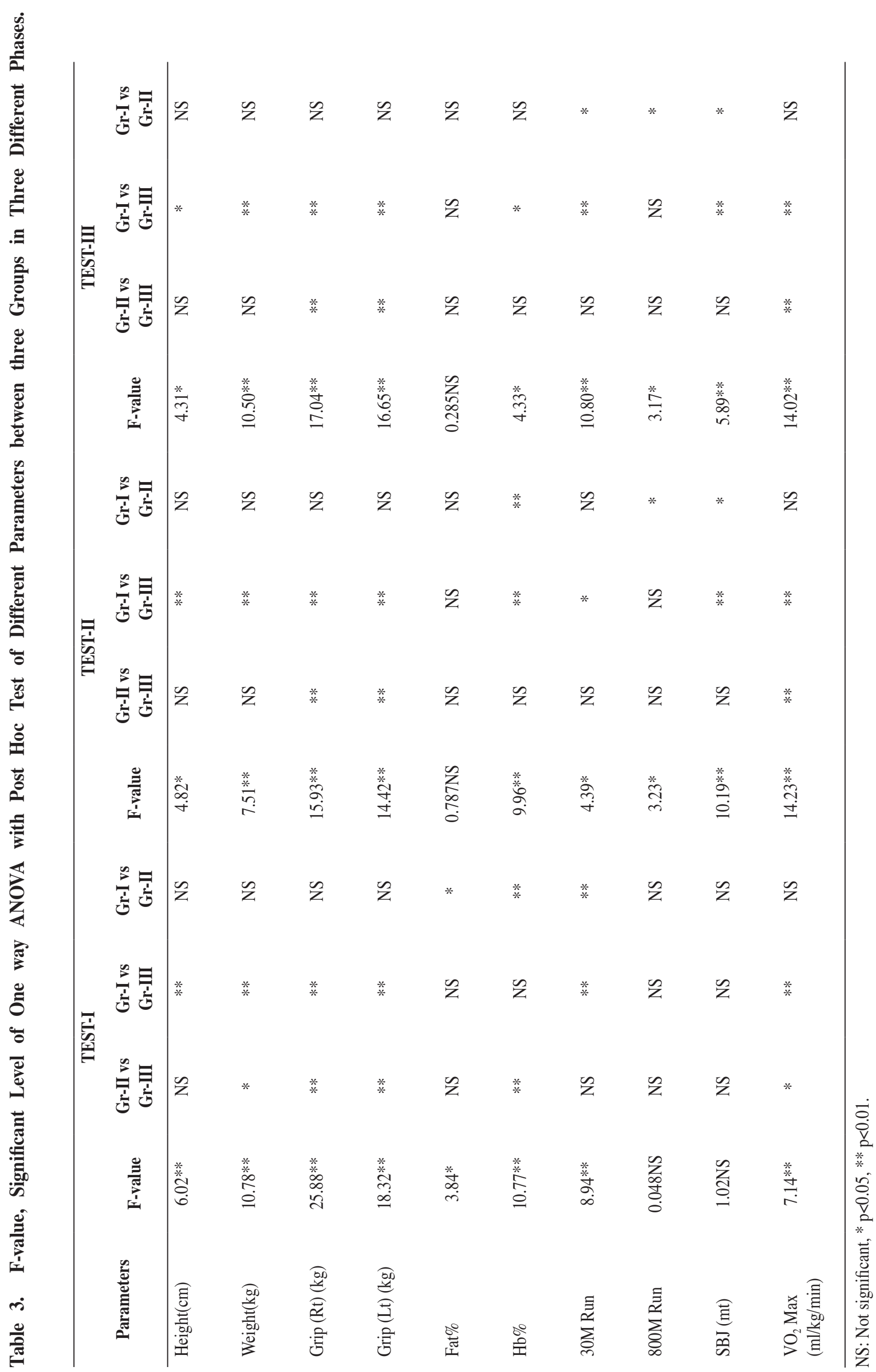




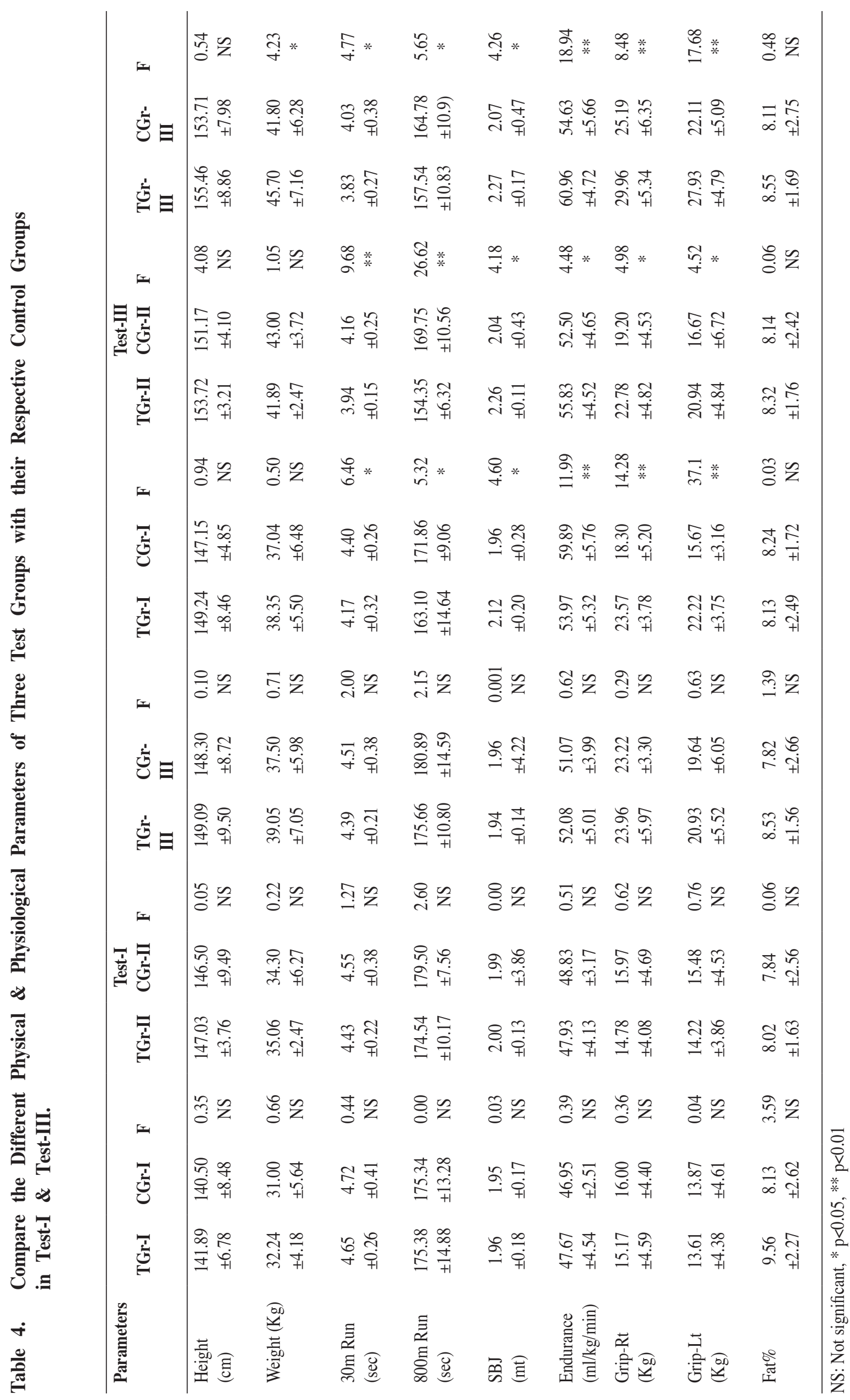




\section{Discussion}

It has been observed from the present findings that except body fat\% in Gr-II boys all other anthropometric \& physiological parameters (such as height, weight, right and left hand grip strength, haemoglobin \%, 30 meter flying start, standing broad jump, 800 meter run and aerobic capacity) have increased significantly in all three test groups following 18 months of formal training (Table 2). It is well accepted that training has augmented the physical and physiological status and athletic proficiency of these preadolescent children. Many investigators have also concluded that a certain amount of physical activity is necessary for normal growth \& development (Micheli, 1984; Adams, 1983; Astrand, 1963) and that moderate physical training can augment and optimize the growth in children (Adams, 1983; Errikson, 1972; Ekblom, 1969; Astrand, 1963). The spurt in growth and development that occurs during adolescence, results in significant improvement in almost all physical and physiological parameters in a growing child. In the present study, all the subjects belonged to a preadolescent age (i.e. GrI9, GrII-10 and GrIII-11 years respectively) at the time of induction, with one of the group (group III- 11 years) at the trigger point of adolescence. So it is difficult to conclude the fact from these initial findings that the observed increases in above mentioned anthropometric and physiological parameters (Table 1) is only because of the augmenting effect of training. Such improvements may also result from the growth spurt that occurs during the adolescence period, or at least some part of this improvement can be attributed to the normal growth and development process of the subjects. Moreover, it is quite likely that different age group having different physiological status of their specific age groups, which will respond differently to a given training. To establish the fact that, whether the observed increase in different parameters in each group (Table 2) is an effect of 18 months training or due merely because of their normal growth and development. The present study also compared the improvements of different parameters in subjects belonging to the three test groups with their respective control groups having almost identical mean age and physiological status to their respective test groups at the time of induction. As the subjects belonging to the control group did not undergo any formal training and led a sedentary lifestyle during the corresponding period of 18 months. To ascertain the response of training in different age group, the present study also compared the improvement of three test groups in respect of different physical and anthropometric parameters following training.

When the response of training was compared in three different test groups (Table 3), it was found that before training (i.e. in test-I), values of all the parameters except 800 meter run and standing broad jump were significantly higher in case of group III (11 years) followed by Group II (10 years) and Group I ( 9 years). Following training, significant differences still existed between the three test groups in all the physical \& physiological parameters except body fat $\%$. These findings suggest that response of training and physical activities are more prominent in case of more aged group-III subjects who were at the verge of their adolescence as compared to the other two subgroups. It has been hypothesized that a maturational threshold (Grodjinovsky, 1980) or a trigger point (Katch, 1983) may exist below which the effect of training will be minimal. Gilliam and Freedson (1980) stated that a maturational factor may determine a child's potential for physiological alterations to occur consequent to physical training. Armstrong (1998) had demonstrated a significant effect of maturation on peak $\mathrm{VO}_{2} \max$ independent of body mass in 12 years old boys \& girls. It has also been reported that training initiated one year before the period of rapid growth during puberty induced remarkable increases in peak $\mathrm{VO}_{2}$ (Mirwald, 1986). When test group-III compared to their respective sedentary control counterpart, it was observed that a significant improvement in all parameters in the course of 18 months of study (i.e. before and after 18 months), except height \& body fat \%. In test group II and group I, all the parameters except height, weight \& body fat $\%$ exhibited significant improvement over 18 months period as compared to their sedentary counterparts. This finding indicates that training has definite augmenting effect in all physical and physiological parameters.

It is well established that isometric strength (hand grip strength) increased with age (Almuzaini, 1999; Blimkie, 1998; Gaul, 1996; Blimkie, 1989). Martin and Malina (1998) stated that peak power generally increases with age from middle childhood into adolescence. It was also observed in the present study, that grip strength of control groups has improved but was not significant as compared to their respective test groups. It was further observed that both SBJ \& 30m flying start have increased significantly after 18 months of training. These two tests represent player's horizontal jumping performance and 
running speed respectively. Maximum strength appears to be a major factor influencing performance in a variety of different sports (Stone et al. 2004) when a training program is properly structured with regard to frequency, mode, intensity and duration of program can increase strength in pre-adolescents and adolescents (Falk, 1996; Blimkie, 1993; Faigenbaum, 1993; Ramsay, 1990). In the present study such gain in strength occurred without concomitant muscle hypertrophy rather than may be attributed to neuromuscular "learning" in which training increases the number of motor neurons that will fire with each muscle contraction (Ozmun, 1994; Ramsay, 1990; Kraemer, 1989). It has been well established by Blimkie (1998) that the skeletal muscle is the tissue responsible for force generation during growth and these force /power have a significant effect on improvement in speed (Kanehisa 1983).

Some studies have reported that training induce improvement in peak $\mathrm{VO}_{2} \max$ (Weltmani, 1987; Savage, 1986) in preadolescent children, where as others have observed no significant changes in peak $\mathrm{VO}_{2} \max$ after training (Becker, 1983; Gilliam, 1980) and (Mirwald, 1981; Kobayashi, 1978) but from the present findings it was seen that the aerobic capacity was improved significantly in Gr-I, Gr-II \& Gr-III boys. Training in young athletes has been shown to increase in aerobic capacity of prepubertal children above the normal increase attributable to age, physical growth \& maturation (Baxter-Jones 1993). In the present study hemoglobin concentration was found to be increased in training groups. Many investigators have examined the influence of various exercise regimes on serum erythropoietin levels (Klausen, 1993a; Weight, 1992; Schwandt, 1991; De Paoli, 1988) which partially controls the hemoglobin concentration (Ekblom, 1996). Increase in erythropoietin activity or level following training can be attributable to the increased concentration of haemoglobin (Ricci et al. 1988). Haemoglobin concentration markedly improves for delivery of oxygen to working muscle and hence can have a significant augmenting effect on $\mathrm{VO}_{2} \max$ as found in this study. In the present study the increase in aerobic capacity is also reflected in improvement in 800 meter run following training. But body fat $\%$ is actually decreased following training in adolescent \& pre adolescence children. It is reasonable to assume that excess body fat $\%$ can have a negative influence on locomotion and athletic proficiency (Cureton, 1978). Decrease in body fat \% is a natural corollary of increased physical activity or training. Likewise, the present study indicated that the percent improvement in body fat over 18 month's period was higher in sedentary control subgroup as compared to the training counterparts. So any increase in body weight or higher body masses in an athlete can be attributed to an increased fat free mass.

It can be concluded that training has significant augmenting effect in physical and physiological parameters of preadolescent children such as height, weight, $\mathrm{VO}_{2}$ $\max , \mathrm{Hb}$ concentration, 30meter fly, 800 meter run, standing broad jump and right and left grip strength. However training has also a negative effect on body fat $\%$ following training in adolescent \& pre adolescence children. This investigation also established that the effect of training is more pronounced in subjects belonging to higher age group. The children who are at the threshold of their adolescence respond more positively to a given training as compared to the children belonging to comparatively at lower age group.

\section{Acknowledgements}

The authors are indebted to the training of Tripura Sports School Government of Tripura those who were subjected voluntarily for the study. The authors express their gratitude to SAI, Eastern center Kolkata providing facilities/equipments for the study. The author also thanks Mr. Prasenjit Patra for his assistance in statistical analysis.

\section{References}

Adams, E. (1983). A comparative anthropometric study of hard labor during youth as a stimulator of physical growth of young colored women. Research Quarterly 9, 102-8.

Almuzaini, K.S. (1999). Association between body composition and physical performance relative to chronological age for Saudi boys aged 6-15 years. Saudi J Sports Med 4(1):28-40 (In Arabic).

Armstrong, N., \& Welsman, J. R.,\& Kirby, B.J. (1998). Med Sci Sports Exerc, 30, 165-169.

Armstrong, N., \& Welsman, J. (1990). Young people and physical activity. Oxford: University Press, pp 122-36. 
Astrand, P.O. et al. (1963). Girl Swimmers. Acta Paediatric Scandanavica, 147(suppl.), 1-75.

Bar-Or, O. (1989). Trainability of the pre-pubescent child. The Physician and Sports Medicine 17, 64-82.

Barrow, H.M., \& Rosemary McGee. (1979). A Practical Approach to Measurement in Physical Education. Philadelphia, Lea \& Febiger, pp 189-192.

Baxter-Jones, A., Goldstein, H., \& Helms, P. (1993). The development of aerobic power in young athletes. $J$ Appl Physiol 75, 1160-7.

Becker, D.M., \& Vaccaro, P. (1983). Anaerobic threshold alterations caused by endurance training in young children. J Sports Med 23, 445-9.

Blair, S.N. (1992). Are American children and youth fit? The need for better data. Res $Q$ Exerc Sport, 63, $120-123$

Blimkie, C.J., \& Sale, D.G. (1998). Strength development and trainability during childhood. In: Van Praagh E (ed). Pediatric Anaerobic Performance. Champaign, IL: Human Kinetics, pp. 193-224.

Blimkie, C.J. (1993). Resistance training during preadolescence. Sports Med 15, 389-407.

Blimkie, C.J. (1989). Age and sex-associated variation in strength during childhood: anthropometric, morphologic, biomechanical, endocrinologic, genetic and physical activity correlates. In: Gisolf $\mathrm{CV}$, Lamb DR (eds). Perspectives in Exercise Science and Sports Medicine. Volume 2: Youth, Exercise and sport. Indianapolis (IN): Benchmark Press, pp 99-163.

Boreham, C., Paliczka, V.J., \& Nichols, A.K. (1990). A comparison of the PWC 170 and 20-MST tests of aerobic fitness in adolescent schoolchildren. J Sports Med Phys Fitness 30, 19-23.

Carter, JEL. (1970). The somatotypes of athletes: a review. Human Biology 42, 535-569.
Cureton, K.J., Sparling, P.B., Evans, B.W., Johnson, S.M., Kong, U.D., \& Purvis, J.W. (1978). Effect of experimental alterations in excess weight on aerobic capacity and distance running performance. Medicine and Science in Sports and Exercise, 10, 194-199.

Dacie, J.V., \& Lewis, S.M. (1975). Practical Haematology. Churchill Living Stone, Edinburgh, Great Britain, pp 31.

De Paoli Vitali, E., Guglielmini, C., \& Casoni, I. et al. (1988). Serum erythropoietin in cross-country skiers. International Journal of sports Medicine 9, 99-101.

Dey, S.K., Sinha, S.K., Debray, P. (1997). A Comparative Study of Selected Anthropometric \& Motor Quality profiles of Girls (8-14 years) of Eastern and North Eastern Region of India. SAI Scientific Journal, 20 (40), $5-24$.

Durnin, JVGA., \& Womersley, J. (1974). Body fat assessed from the total body density and its estimation from skinfold thickness measurements on 481 men and women aged 16-72 years. Brit J Nutr 32, 77-97.

Ekblom, B. (1996). Blood doping and erythropoietin. The effects of variation in haemoglobin concentration and other related factors on physical performance. American Journal of Sports Medicine 24, S40-S42.

Ekblom, B. (1969). Effect of physical training on oxygen transport system in man. Acta Physiologica Scandanavica, 328 (suppl.),1-45.

Eriksson, B. (1972). Physical training, oxygen supply \& muscle metabolism in 11-13 years -old boys. Acta Physiologica Scandanavica, 384 (suppl.),1-48.

Eston, R.G., Fu, F., \& Fung, L. (1995). Validity of conventional anthropometric techniques for predicting body composition in healthy Chinese adults. $\mathrm{Br} J$ Sport Med 29 (1), 52-56.

Faigenbaum, A.D., Zaichkowsky, L.D., Westcott, W.L., Micheli, L.J., \& Fahlandt, A.F. (1993). The effects of a twice-a-week strength training programe on children. Pediatr Exerc Sci 5, 339-346. 
Falk, B., \& Tenenbaum, G. (1996). The effectiveness of resistance training in children. A meta-analysis. Sports Med, 3,176-186.

Gaul, C.A. (1996). Muscular strength and endurance. In: Docherty D (ed). Measurement in Pediatric Exercise Science. Champaign IL: Human Kinetics, pp 225-258.

Gillian, T.B., \& Freedson, P.S. (1980). Effects of a 12 week school physical fitness program on peak VO2, body composition and blood lipid in 7 to 9 years old children. $J$ Sports Med 1, 73-8.

Grodjinovsky, A., Inbar, O., \& Dotan, R. et al. (1980). Training effect on anaerobic the performance of children as measured by the wingate anaerobic test. In: Berg K, Eriksson B (eds). Children and exercise IX. Baltimore. University Park Press, pp 139-45.

Kanehisa, H., \& Miyashita, M. (1983). Specificity of velocity in strength training. Eur J Appl Physiol 52, 104-106.

Katch, V.L. (1983). Physical conditioning of children. J Adolesc Health Care 3, 241-6.

Klausen, T., Breun, L., Fogh-Andersen, N., Bennett, P., \& Hippe, E. (1993a). The effect of short and long duration exercise on serum erythropoietin concentrations. European Journal of Applied Physiology 67, 213-217.

Kobayashi, K., Kitamura, K., \& Miura, M. et al. (1978). Aerobic power as related to body growth and training in Japanese boys: a longitudinal study. $J$ Appl Physiol 44, 666-72.

Kraemer, W.J., Fry, A.C., Frykman, P.N., Conroy, B., \& Hoffman, J. (1989). Resistance training and youth. Pediatr Exerc Sci 1, 336-350.

Krahenbuhl, G.S., Skinner, J.S., \& Kohrt, W.M. (1985). Developmental aspects of maximal aerobic power in children. Exerc Sport Sci Rev 13, 503-38.

Leger LA, Lambert J (1982). A maximal multistage 20$\mathrm{m}$ shuttle run test to predict VO2max. Eur J Appl Physiol Occup Physiol 49:1-12.
Malina, R.M. (1994). Physical activity and training: effects on stature and the adolescent growth spurt. Med Sci Sports Exerc 26, 759-66.

Malina, R.M., \& Bouchard, C. (1991). Growth, Maturation \& Physical Activity. Champaign, IL: Human Kinetics.

Martin, G.C., \& Malina, R.M. (1998). Developmental variations in anaerobic performance associated with age and sex. In: E.Van Praagh (Ed). Pediatric Anaerobic Performance. Champaign IL: Human Kinetics, pp 45-93.

van Mechelen, W., Hlobil, H., \& Kemper, H.C. (1986). Validation of two running tests as estimates of maximal aerobic power in children. Eur J Appl Physiol Occup Physiol 55, 503-6.

Micheli, L. (1984). Pediatric \& Adolescent Sports Medicine. Philadelphia: Saunders WB.

Mirwald, R.L., \& Baily, D.A. (1986). Maximal aerobic power. Ontario: Sports Dynamics, London.

Mirwald, R.L., Baily, D.A., \& Cameron, N., et al. (1981). Longitudinal Comparison of aerobic power on active and inactive boys aged 7 to 17 years. Ann Hum Biol 8, 405-14.

Ozmun, J.C., Mykesky, A.E., \& Surburg, P.R. (1994). Neuromuscular adaptations following prepubescect strength training. Med Sci Sports Exerc 26, 510-514.

Pate, R.R., \& Ward, D.S. (1990). Endurance exercise trainability in children and youth. In: Grana WA, Lombardo JA, Sharkey BJ, et al. (eds). Advances in sports medicine and fitness. Chicago: Year Book Publishers, 3, 37-55.

Raghavan, K.V., Singh, D., \& Swaminathan, M.C. (1971). Height and weights of well nourished Indian school children. Ind. J .Med. Res 59, 1648.

Ramsay, J.A., Blimkie, C.Z., Smith, K., Garner, S., MacDougall, J., \& Sale, D.G. (1990). Strength training effects in pre pubescent boys. Issues and controversies. Med Sci Sports Exerc 22, 605-614. 
Ricci, G., Masotti, M., De Paoli Vitali, E., Vedovato, M., \& Zanotti, G. (1988). Effects of exercise on haematologic parameters, serum iron, serum ferritin, red cell 2,3-diphosphoglycerate and creatin contents, and serum erythropoietin in long-distance runners during basal training. Acta Haematologica 80, 95-98.

Rowland, T.W., \& Boyajian, A. (1995). Aerobic response to endurance exercise training in children. Pediatrics 96, 654-8.

Savage, M.P., Petratis, M.M., \& Thomson, W.H., et al. (1986). Exercise training effects on serum lipids of prepubescent boys and adult men. Med Sci Sports Exerc 18, 197-204.

Schwandt, H.J., Heyduck, B., Gunga, H.C., Rocker, L. (1991). Influence of prolonged physical exercise on the erythropoietin concentration in blood. European Journal of Applied Physiology 63, 463-466.

Shephard, R.J., \& Lavallee, H. (1993). Impact of enhanced physical education in the prepubescent child: Trois Rivieres revisited. Pediatric Exercise Science 5, 17789.

Shephard, R.J. (1992). Effectiveness of training programmes for prepubescent children. Sports Med 13, 194-213.

Shephard, R.J., Lavallee, H., Rajic, M., Jequier, J-C., \& Volle, N. (1984). Body dimensions of Quebecois children. Ann Hum Biol 11, 243-52.

Siri, W.E (1961). Technique for measuring body composition. National academy of science nation research council. Brojak JA (ed). Washington USA, pp 223-244.

Stone, M.H., Sands, W.A., Carlock, J., Callan, S., Dickie, D., Daigle, K., Cotton, J., Smith, S.L., \& Hartman, M. (2004). The importance of isometric maximum strength and peak rate-of-force development in sprint cycling. Journal of Strength and Conditioning Research 18, 878-884.
Tanner, J.M. (1964). The Physique of the Olympic Athletes. George Allen and Unwin, London.

Van Praagh, E. (2000). Development of anaerobic function during childhood and adolescence. Pediatr Exerc Sci 12, 150-173.

Veadmir, M., \& Zatsiorsky. (1995). Science and practice of strength training. Champaign, IL: Human Kinetics, pp 4.

Weight, L.M., Alexander, D., Elliot, T., \& Jacobs, P. (1992). Erythropoietic adaptations to endurance training. European Journal of Applied Physiology 64, 444-48.

Weltman, A., Janney, J., \& Rians, C.B., et al. (1987). The effects of hydraulic-resistance strength training on serum lipid levels in prepubertal boys. Am J Dis Child 141, 777-80.

\section{Correspondence}

Dr. S. K. Dey

Scientific Officer

Human Performance Laboratory

Sports Authority of India

Netaji Subhas Eastern Centre

Salt Lake City, Kolkata-700098

Email: drsk_dey@rediffmail.com 